JURNAL PENDIDIKAN ISLAM IQRA' Vol. 11. Nomor 1

Fakultas Tarbiyah dan Ilmu Keguruan [FTIK]

IAIN Manado

\title{
PENDIDIKAN PADA TIGA KERAJAAAN BESAR (KERAJAAN TURKI, USMANI, SAFAWIY DI PERSIA DAN MOGHUL DI INDIA)
}

\author{
Ismail Usman \\ IAIN Manado
}

\begin{abstract}
Abstrak
Tulisan ini mengkaji tentang dinamika pendidikan pada tiga kerajaan besar dalam sejarah kerajaan Islam yakni Moghul, Utsmani dan Safawi. Ketiga kerajaan ini pernah berjaya pada masanya dan akhirnya mengalami kemunduran yang luar biasa. Faktornya bermacam-macam salah satu diantaranya disebabkan karena kurangnya perhatian kerajaan pada bidang pendidikan. Persoalan pokok pada kajian ini adalah menguraikan bagaimana sistem pendidikan pada tiga kerajaan tersebut dan pendidikan yang seperti apa yang menjadi fokus dari ketiga kerajaan ini. Kajian ini menggunakan metode penelitian pustaka dengan pendekatan studi komparatif. Hasil kajian menunjukkan bahwa (1) Pada Kerajaan Usmani kegiatan pendidikan yang sangat nampak pada dasarnya adalah pendidikan kemiliteran dan pemerintahan; kehidupan seni, budaya (arsitektur), bidang keilmuan, dan ilmu-ilmu keagamaan. (2) Pada Kerajaan Safawi, pendidikan yang menonjol adalah bidang perekonomian; kehidupan seni budaya arsitektur, bidang keilmuan dan ilmu-ilmu keagamaan (3) Pada Kerajaan Moghal kegiatan pendidikan yang nampak berkembang adalah kegiatan pendidikan disegala bidang seni. Kesimpulan dari kajian ini adalah setiap kerajaan memiliki model, cara dan tujuan yang berbeda dalam mengembangkan dunia pendidikan berdasarkan kepentingan Negara di masa depan.
\end{abstract}

Kata Kunci: Kerajaan, Islam, Pendidikan, Moghul, Safawiy, Usmani

\section{Pendahuluan}

Kegiatan pendidikan adalah upaya untuk mencerdaskan kehidupan bangsa dan kehidupan bernegara dari segala aspek kehidupan manusia. Baik dari aspek politiknya dan pertahanan keamanan maupun aspek-aspek yang lainnya. Majunya pendidikan dalam suatu bangsa makin maju pula tingkat kecerdasan dan kemakmurannya. Tetapi sebaliknya, terhambatnya pendidikan dalam suatu bangsa dan negara, akan terhambat pula kecerdasan dan kemakmuran rakyat, bahkan 
JURNAL PENDIDIKAN ISLAM IQRA' Vol. 11. Nomor 1

Fakultas Tarbiyah dan Ilmu Keguruan [FTIK]

IAIN Manado

keamanan bangsa dan negara pun akan terancam. ${ }^{1}$ Dalam hal ini Negara tergantung pada kecerdasan bangsa dan ketahanan nasional yang dimilikinya. Oleh karena itu sebagai penguasa, penentu kebijakan harus mampu memandang negara dan bangsanya sebagai satu kesatuan yang utuh, dengan berupaya melakukan pembangunan di segala bidang, terutama pada sektor pendidikan, ${ }^{2}$ baik yang bersifat material maupun immateril. Dengan terwujudnya kedua unsur ini, mendorong terbentuknya masyarakat madaniyah.

Dari pengalaman sejarah, suatu bangsa dapat ditaklukkan oleh musuhnya karena keterbelakangan dibidang pendidikan, misalnya Indonesia telah terbelenggu $+3 \quad 1 / 2$ abad di bawah kekuasaan para penjajah. Demikian juga kerajaan-kerajaan Islam seperti tiga kerajaan Islam yang pernah jaya yang dikenal dengan kerajaan Usmani, Safawi dan Moghul, pada akhirnya mengalami kemunduran $(700-800 \mathrm{M})$ yang drastis. ${ }^{3}$ Yang pada hakekatnya akibat karena kelemahan pada faktor pendidikan dari segala aspeknya. Sehubungan hal tersebut, dalam makalah ini, penulis mencoba melihat kegiatan-kegiatan pendidikan pada ketiga kerajaan tersebut. Dengan rumusan masalah "Kegiatan-kegiatan pendidikan apakah yang mengalami perkembangan (menonjol) pada ketiga kerajaan itu"?

\section{Kegiatan Pendidikan pada Kerajaan Turki Usmani}

Kerajaan Usmani disebut pula Otonom yang berasal dari nama nenek moyang mereka, yakni Usman - nama khalifah ideal yang kemudian disebut Usmaniyah dan akhirnya disebut Ottoman. Ottoman adalah salah satu dinasti besar dan alam didunia. Kerajaan ini telah berkuasa sebanyak 36 sultan sejak tahun 1300 - 1922 M. ${ }^{4}$ Usman adalah sultan pertama, lalu diikuti sultan lainnya dengan dasar

\footnotetext{
${ }^{1}$ Ikatan Dosen Kewiraan Sulawesi, Pendidikan Kewiraan, (Ujung pandang: Yayasan Pengembangan Ilmu dan Teknologi. 1990). h. 53

${ }^{2}$ Lihat juga Quraish Shihab, Membumikan Al-Qur'an, ( Bandung: Mizan, 1998). h. 123.

${ }^{3}$ Badri Yatim, Sejarah Peradaban Islam Dirasah Islamiyah II, (Jakarta: Raja Gravindo Persada, 1993). h. 155.

${ }^{4}$ Akbar S. Ahmed, Discovering Islam. Making Sence Of Muslim History and Society Terjemahan Nunding. dkk., Citra Muslim Tinjauan sejarah dan Sosiologi (Jakarta: Erlangga, 1992). h. 71.
} 
JURNAL PENDIDIKAN ISLAM IQRA' Vol. 11. Nomor 1

Fakultas Tarbiyah dan Ilmu Keguruan [FTIK]

IAIN Manado

hubungan darah dan garis keturunan bapak. Kerajaan ini mencapai puncak kejayaannya pada masa pemerintahan Suiaiman pada abad ke-16. ${ }^{5}$ Pada tahun 1529 pasukan Sulaiman hampir menguasai Wina.

Kegiatan pendidikan yang menonjol pada masa kejayaan Sultan Sulaiman adalah di bidang kesusastraan, kesenian dan arsitektur. Karena itu, pada masa pemerintahan Sulaiman banyak gereja diubah (dijadikan) masjid. Salah satu contoh paling terkenal adalah penggantian gereja "Santa Sophia" (gereja megah dalam dunia Kristen) menjadi Mesjid Agung terkenal di Istanbul. Seorang arsitek yang sangat diakui dan terbaik pada masa sultan ini adalah Sina. la telah membangun masjid Sulaimaniyah 16 kali lebih tinggi daripada Santa Sophia. Beliau ini telah membangun 80 buah bangunan dengan gaya arsitekturnya sendiri yang masih eksis sampai sekarang. Adapun sistem pemerintahan yang dianutnya adalah bersilat eklektik, memungkinkan terciptanya sistem kenaikan pangkat atau status yang didesain atas kemampuan. Maksudnya bilamana seseorang telah menjadi muslim terlepas apakah ia orang Arab, slav, Armenia atau orang Turki maka ia berhak menduduki jabatan tinggi di dalam wilayah kerajaan, kecuali jabatan sultan ditentukan dengan dasar hubungan darah. ${ }^{6}$

Istanbul sebagai ibukota kerajaan Turki Usmani, menjadi sebuah negara adidaya pada masa kejayaannya, sebagaimana halnya dulu dengan Konstantinopel pada masa kerajaan Romawi Timur. Dimana perkembangan kebudayaan dan pendidikannya banyak diwarnai atau berpaduan dengan bermacam-macam kebudayaan lain seperti pengajaran etika dan politik dipengaruhi bangsa Persia. Dalam bidang kemiliteran dan pemerintahan diwarnai oleh kebudayaan Byzantium. Dan pendidikan dalam bidang ilmu dan keagamaaan. Prinsip-prinsip kemasyarakatan dan hukum, ilmu khat (huruf Arab) dipengaruhi oleh bangsa Arab, bahkan huruf Arab dijadikan huruf resmi kerajaan. ${ }^{7}$

\footnotetext{
${ }^{5}$ Seluruh Afrika Utara, kecuali Maroko, berhasil dijadikan bagian dari kerajaan. Wilayah kekuasaannya melebar dari Budapes sampai ke Yaman, mulai dari Baqdad sampai ke Aljazair.

${ }^{6}$ Ibid., h.72

${ }^{7}$ Badri Yatim, op.cit., h. 288. Lihat puia Akbar S. Ahmed. op.cit., h. 72.
} 
JURNAL PENDIDIKAN ISLAM IQRA' Vol. 11. Nomor 1

Fakultas Tarbiyah dan Ilmu Keguruan [FTIK]

IAIN Manado

Disamping sarana-sarana peribadatan, ${ }^{8}$ nampak megah pada masa kejayaannya. Juga nampak sarana-sarana yang lainya seperti istana-istana, villavilla yang megah, sekolah, asrama, rumah sakit, panti asuhan, penginapan, pusatpusat terekat, dan lain-lain. Sarana-sarana tersebut berpusat di ibu kota. Jauh sebelumnya, kegiatan pendidikan yang disebutkan di atas, telah berkembang kegiatan ilmu pengetahuan dan kehidupan seni budaya dalam masa kerajaan Usmani. Dalam bidang ilmu pengetahuan, muncul karya ilmu kalan (teologi), karya tafsir, hadis, tasawuf, hukum: karya tentang ilmu mantiq, ilmu shib, karya ilmu peperangan dan persenjataan, karya ilmu politik, dan lain-lain. Selain itu, juga berkembang ahli musik beserta karyanya. Demikian juga ahli sejarah (historian), beserta karyanya. ${ }^{9}$ Dan dalam bidang kehidupan seni budaya disebut zaman bagi kebudayaan islam karena tidak banyak yang harus dicatat sebagai perkembangan seni budaya, kecuali tentang seni, bahasa yang memang ada perkembangannya. Sekalipun tersendat-sendat, misalnya saja dalam bidang seni bahasa yang meliputi . puisi, ${ }^{10}$ prosa, dan ilmu bahasa.

Semua bidang tersebut, baik ilmu pengetahuan maupun kehidupan seni budaya muncul diawali "Gerakan Wahabi" yang dikenal dengan Bintang Kebangkitan Kembali, dunia Islam, yaitu lahirnya seorang muslim besar Muhammad bin Abdul Wahab. ${ }^{11}$ (1116 - .1206 H), lahir di daerah Uyainah Nejad. Dengan kehadirannya sangat berpengaruh ke seluruh penjuru dunia Islam.Setelah

\footnotetext{
${ }^{8}$ Seperti masjid al-Ansharii- tempat pelantikan pada Sultan Usmani (Masjid Agung Sultan Muhammad al-Fatih. Masjid Abu Ayub ai-Anshari- tempat pelantikan pada Suitan Usmani Masjid Bayazid dengan gaya Persia dan Masjid S r! aim ari ai-Qamni) semuanya tergoiong masjid-masjid penting. Lihat Badri Yatim, op.cit., h. 289

${ }^{9}$ A. Hasjmy, Sejarah Kebudayaan Islam ( Jakarta : Bulan Bintang. 1993). h. 395 - 400.

${ }^{10}$ Puisi mengalami kemunduran dan kelesuan yang dahsyat dalam zaman Usmani, hampir tidak muncul para penyair yang mempunyai kepribadian yang kuat, yang sanggup menghadapi zaman gelap itu dengan sinar jiwanya yang menembus. Karena mereka menganggapnya, puisi itu hanya sebagai permainan kata yang kering dan tiada berisi, apalagi berjiwa, sehingga seakan-akan mereka mengorbankan waktu dengan penyusunan kata yang Pada berguna dimana jiwa dan isi dari puisi telah menjadi korban gaya, bahasa yang dingin. Namun menurut Jasji Zaidan bahwa hanya 49 penyair yang dianggapnya menonjol, diantaranya. Asiyah Bani Umayyah dan seterusnya, Ibid., h. 403 - 404.

${ }^{11}$ Salah satu karyanya yang sangat berpengaruh adalah "Lam'asy Syibah fi Sirah Muhammad bin Abdul Wahab wa mazhabi, Ibid., h. 395.
} 
JURNAL PENDIDIKAN ISLAM IQRA' Vol. 11. Nomor 1

Fakultas Tarbiyah dan Ilmu Keguruan [FTIK]

IAIN Manado

terjadi persaingan serius antara dua kubu, restorasionin ${ }^{12}$ dan modernis sepanjang abad 18 dan 19, maka keluarlah kubu modernisasi Eropa. Ketika itu. Salim 111 (1789 - 1807 M) sebagai sultan memperlakukan program reformasi yang komprehensif yang adalah mendirikan sekolah teknik untuk mendidik kader-kader bagi rezim baru, meningkatkan pendapatan sektor pajak, memberikan pelatihan teknik kepada pasukan militer yang ditangani oleh penasehat militer Eropa. ${ }^{13}$

Pada masa pemerintahan Mahmud 11 (1809 - 1839) program reformasi semakin nyata, terutama dalam bidang pendidikan militer dan mendirikan sekolah yang berorientasi terhadap Barat, dan menerapkan konsep sentralisasi negara yang lebih radikal, dijalankan oleh sebuah kerajaan absolut. Dalam mengembangkan kekuatan politiknya, ia menganut sikap persekutuan dan toleransi. Sikap toleransi ini memberikan pelajaran bagi Kristen bahwa bilaman ada peperangan dilancarkan tidak lagi dikaitkan dengan ideologi keagamaan. ${ }^{14}$ Dari uraian di atas dapatlah digarisbawahi kegiatan pendidikan yang menonjol pada kerajaan Usmani adalah pada bidang kemiliteran dan pemerintahan bidang ilmu pengetahuan dan budaya dan bidang keagamaan. Dalam bidang agama, ulama berperan dalam kerajaan dan masyarakat dalam memberi fatwa resmi terhadap problem keagamaan yang dihadapi masyarakat.

\section{Kegiatan Pendidikan pada Kerajaan Safawi}

Masa kekuasaan Abbas 1 merupakan puncak kejayaan. Kerajaan Safawi. Secara politik, ia mampu mengatasi berbagai kemelut di dalam negeri yang mengganggu stabilitas negara dan berhasil merebut kembali wilayah-wilayah yang pemah direbut oleh kerajaan lain pada masa raja-raja sebelumnya. ${ }^{15}$ Selain kejayaan tersebut juga mengalami banyak kemajuan dalam bidang lain, seperti

\footnotetext{
${ }^{12}$ Menghendaki pemberlakuan kembali undang-undang (zaman Sulaiman al-Gannumi dan menentang, setiap perubahan yang memberikan kesempatan kepada kekuatan Eropa dan Kristen. Lihat Ira. M. Lapidus, A History of Islamic Societies, Penerjemah, Ghuiran A. Mas'adi, sejarah Sosial Umat Islam. Edisi 1 (Jakarta: PT. Raja Grafindo Persada, 1999). h. 72-73.

${ }^{13}$ Ibid., h. 373

${ }^{14}$ Natsir Mahmud,Orlentalisme Al-Qur'an di Masa Barat: Sebuah Studi Evaluative, (Semarang: Dina Utama, t.th.), h. 49.

${ }^{15}$ Badri Yatim, op.cit., h. 143.
} 
JURNAL PENDIDIKAN ISLAM IQRA' Vol. 11. Nomor 1

Fakultas Tarbiyah dan Ilmu Keguruan [FTIK]

IAIN Manado

bidang pendidikan dan keilmuan, yang meliputi bidang ekonomi, ilmu pengetahuan, dan pembangunan fisik dan seni.

\section{Bidang Ekonomi}

Perkembangan pendidikan dalam bidang ekonomi, membuat Kerajaan Safawi pada masa pemerintahan Abbas 1 semakin maju. Dengan kemajuan ini, kepulauan Hurmuuz dan pelabuhan Gumrun (diubah menjadi Bandar Abbas) dikuasainya lalu dijasikan sebagai jalur jagang laut antara Timur dan Barat. Juga dalam bidang pertanian mengalami kemajuan, terutama didaerah Bulan Sabit Subur (forlile Crescent). ${ }^{16}$ Dengan kemajuan perekonomian negara tersebut, menjadilah Ibukota Kerajaan Safawi, Isfahan menempati posisi yang sangat penting untuk tujuan politik dan ekonomi bagi negara Iran yang berpusat di Kerajaan Safawi. Pada masa Abbas 1, dan Abbas H (1642 - 1666) kegiatan pendidikan dan keagamaan semakin nampak, ditandai dengan adanya sejumlah sekolah dan perguruan tinggi (48 buah) dan 162 masjid, nampak pual fasilitas lainnya yang mengelilingi kota kerajaan. ${ }^{17}$

\section{Bidang Ilmu Pengetahuan}

Dalam sejarah Islam, bangsa Persia dikenal sebagai bangsa yang berpendahan tinggi dan berjasa mengembangkan ilmu pengetahuan. Sehingga tidak mengherangkan jika tradisi keilmuan terus berlanjut kerajaan safwi. Kegiatan keilmuan banyak diadakan di Majelis Istana, seperti kajian teologi, kesejarahan dan kefilsafatan. Pakar ilmuan yang selalu tampil waktu itu adalah Bahr al-Din alSyaerazi Ibnu Muhammad Damad ahli bidang filosof) ilmu sejarah dan teologi. Dalam bidang-bidang tersebut menurut Badri Yatim, M.A., Kerajaan Safawi jauh lebih berbasil dari dua kerajaan besar Islam lainnya.

\section{Bidang Pembangunan Fisik dan Seni}

\footnotetext{
${ }^{16}$ Ibid., h. 144

${ }^{17}$ Ira M. Lapidus. bagian I dan II. op.cit., h. 452 - 453.
} 
JURNAL PENDIDIKAN ISLAM IQRA' Vol. 11. Nomor 1

Fakultas Tarbiyah dan Ilmu Keguruan [FTIK]

IAIN Manado

Selain kegiatan pendidikan tersebut, juga nampak pendidikan seni dan arsitek yang bukan hanya berpusat pada ibukota istana tetapi juga sampai di daerah pedalaman. Atas kebesaran Syah Abbas ini dapat disertakan dengan dua penting sejamannya - Raja Akbar di Indonesia dan Ratu Elizabeth di Inggris. Di bidang arsitektur bangunan-bangunannya, seperti terlihat pada Masjid Shah yang dibangun tahun $1661 \mathrm{M}$ dan Masjid Syekh Luth Ailah yang dibangun tahun 1603 M, unsur setu lainnya terlihat pula dalam bentuk kerajinan tangan, keramik, karpet permadani dan tenunan, dan lain-lain. Seni lukis ini mulai dirintis sejak zaman Tahmasp I, Raja Ismail Satu (1522 M) mendatangkan seorang pelukis Timur ke Tabriz yang bernama Bizhad. ${ }^{18}$

Kemajuan dalam bidang seni diayomi oleh seniman Persia genius, dtantaranya Syah Ismail dan Syah Tahmasp. Dalam bidang seni kaligrafi juga nampak nyata, kaligrafer yang menjadi pujaan Syah Abbas adalah Ali Riza. Seni lukis miniatur mencapai puncaknya dengan karya lukis yang menggambarkan naskah sastra kalsik, misalnya lukisan Syah Nama yang diperkirakan mencapai 250 karya lukis, salah satu pelukisanya adalah Firdausi. Untuk mendorong perkembangan kesenian tersebut, pihak sultan yang berkuasa senantiasa memperhatikan kesejahteraan (disediakan imbalan yang memadai atau disruh tinggal di istana, apabila mereka tinggal di luar kota - di propinsi yang jauh). ${ }^{19}$ Kemajuan dalam bidang seni tersebut, nampaklah kota Isfahan menjadi salah satu kota yang indah di dunia pada jamannya dengan jumlah penduduk +1 juga jiwa. Keadaan teman kota nampak indah dimata pengunjung, sehingga seorang pengunjung Prancis menayatakan keagungannya dengan ungkapan "Dari arah manapun orang memandang kota itu akan tampak hijau”.

\section{Kegiatan Pendidikan pada Kerajaan Mogul}

Kerajaan Mogul (Moghal) di India berdiri seperempat abad sesudah berdirinya Kerajaan Satawi. Dengan demikian, di antara ketiga kerjaan besar Islam tersebut,

\footnotetext{
${ }^{18}$ Marshal G.S. Hodson, The Venture of Islam, Volume III (Chichago : The University of Chichagi Press : 1981). h. 40

${ }^{19}$ Akbar S. Ahmad, op.cit., h. 77.
} 
JURNAL PENDIDIKAN ISLAM IQRA' Vol. 11. Nomor 1

Fakultas Tarbiyah dan Ilmu Keguruan [FTIK]

IAIN Manado

kerajaan inilah yang berbungsu (mudah). ${ }^{20}$ Pendiri kerajaan ini, adalah Zahiruddin Babur (1428 - 1530) cucu dari Timur Leuk, dan Delhi sebagai ibukota kerajaan. ${ }^{21}$ Kekuasaan Moghai membujur dari perbatasan India di sebelah Timur sampai keperbatasan Syria di sebalah barat. Dan di celah-celah itu pernah turunan Persia dan turunan Arab masing-masing menguasai Persia dan Irak dalam waktu yang relatif singkat. ${ }^{22}$

Kegiatan pendidikan pada Kerajaan Mogul mengalami dua fase, yaitu fase klasik dan fase modernitas. Pada fase klasik, kemajuan pendidikan jauh lebih kompleks, khususnya dalam bidang intelektual, baik ilmu keagamaan, politik, peradaban dan kebudayaan seperti bidang ilmu pengetahuan dan filsafat. Namun dalam fase modern, ilmu keagamaan, umat Islam hanya melakukan taklid kepada iman-iman besar yang lahir pada masa klasik Islam. Sehingga tidak nampak adanya ijtihad mutlak, dalam artian hasil pemikiran yang bebas mandiri dan kalaupun ada mujtahid - maka, ijtihadnya berada dalam biasa batas mazhab tertentu (ijtihad fil al mazhab). ${ }^{23}$ Diantara kegiatan keilmuan yang menonjol pada zaman kladik Moghal adalah ilmu hadis, ilmu-ilmu al-Qur'an, tasawuf, al-thib, ilmu filsafat, ilmu pasti/ilmu binatang, ilmu tabi'yat (ilmu hewan, ilmu alam), ilmu kemiliteran (peperangan). Ilmu berburu dan kecakapan berkuda, serta ilmu politik dan kenegaraan. ${ }^{24}$

Demikian pula ilmu-ilmu kebahasaan menonjol pada saat itu, sekalipun para pengarangnya kebanyakan mensyarahkan kitab-kitab terdahulu, yang telah tersebar luas sampai dewasa ini, terutama kamus-kamus Arab, seperti Lisanul Arab, al-Qomus al-Fiyar, dan lain-lain. Pakar bahasa yang sangat terkenal pada waktu itu, salah satu di antaranya Ibnu Malik al-Taiy (600 - 672 H), kitabnya yang

\footnotetext{
${ }^{20}$ Kerajaan Moghal bukanlah kemajuan pertama di anak benua India Awal kekuasaan Islam diwilayah India teijadi pada masa khalifah al. Walid, dari Dinasti Bani. Ummayah, penaklukan wilayah ini dilakukan oleh tentara Bani Umayyah di bawah pimpinan Muhamma ibn Qasim. Lihat Badri. op.cit., h. 145.

${ }^{21}$ Ibid., h. 147

${ }^{22}$ Lihat A. Hasymy, op.cit., h. 347.

${ }^{23}$ Lihat Badri, op.cit., h. 151

${ }^{24}$ Lihat A. Hasmiy, op.cit., h. $355-362$.
}

Ismail Usman: Pendidikan pada Tiga Kerajaan Besar... 
JURNAL PENDIDIKAN ISLAM IQRA' Vol. 11. Nomor 1

Fakultas Tarbiyah dan Ilmu Keguruan [FTIK]

IAIN Manado

sangat terkenal Al-Fiyah Ibnu Malik. ${ }^{25}$ Akan tetapi dalam kehidupan seni budaya, mereka tidak begitu menonjol, seperti seni puisi, prosa, seni suara, seni rupa, seni pahat, seni lukis, karena disamping mereka tidak diberi peluang atau tempat yang layak oleh para pembesar negara, mereka juga terpukul dengan pendapat yang mengharamkan patung. ${ }^{26}$

Pada masa gerakan mujahidin yang dicetuskan oleh Syah Waliyullah di abad ke 18 yang kemudian diteruskan oleh anaknya Syah Abd. Azis (1475 - 1823) ke generasi selanjutnya. Nampaklah kegiatan pendidikan semakin besar akibat majunya peradaban Barat yang telah mulai dirasakan orang India, baik yang beragama Islam maupun yang beragama Hindu. Sehingga perhatian pemukapemuka Gerajan Mujahidin dalam sektor pendidikan semakin ditingkatkan pada tahun 1857. Diantara pemuka gerakan itu adalah Maulana Muhammad Qasmin Nantawi dan Maulanan Muhammad Ishak (cucu Syah Abd. Azis). Mereka ini telah berusaha mendirikan perguruan tinggi agama dengan nama Darul Ulum Ocoband, yang pada mulanya suatu madrasah kecil di Deoband. ${ }^{27}$

Darul ulum inilah yang kemudian melahirkan ulama-ulama besar India, dan melalui ulama-ulama besar itu Deoband mempunyai pengaruh besar terhadap masyarakat Islam India, terutama kaum awamanya. Kedudukan Deoband ini sama dengan kedudukan Al-Azhar di Mesir. Di perguruan ini, ditonjolkan ide-ide Syah Wahyulah, yaitu diutamakan pemurnian taughid yang dianut umat Islam India dari paham-paham tarekat salah dari kenyakinan aminisme lama. Yang kedua, pemurnian keagamaan mereka dari segala macam bid'ah. Sebenarnya yang ingin diwujudkan Deoband ialah Islam murni sebagaimana pada masa Nabi, sahabat, tabiin, dan sesudahnya. Untuk mempertahankan semua itu Deoband berpegang teguh pada tradisi lama dan mazhab Hanafi. ${ }^{28}$ Perguruan Deoband itu didirikan untuk melawan kekuasaan Inggris dan untuk menentang pendidikan sekuler Barat

\footnotetext{
${ }^{25}$ Ibid., h. 365

${ }^{26}$ Ibid., h. 376-383.

${ }^{27}$ Harun Nasution, Pembaruan dalam Islam; Sejarah pemikiran dan Gerakan (Cet. IX : Jakarta Bulan Bintang, 1992). h. 150 - 162 dan 163.

${ }^{28}$ Ibid., h. 163
} 
JURNAL PENDIDIKAN ISLAM IQRA' Vol. 11. Nomor 1

Fakultas Tarbiyah dan Ilmu Keguruan [FTIK]

IAIN Manado

yang dibawa Inggris dan juga sebagai reaksi terhadap usaha misi Kristen yang datang ke India bersama Inggris.

\section{Penutup}

Dari beberapa uraian di atas dapatlah ditarik kesimpulan sebagai berikut. Pertama, pada Kerajaan Usmani kegiatan pendidikan yang sangat nampak pada dasarnya adalah pendidikan kemiliteran dan pemerintahan; kehidupan seni, budaya (arsitektur), bidang keilmuan, dan ilmu-ilmu keagamaan. Kedua, pada Kerajaan Safawi, pendidikan yang menonjol adalah bidang perekonomian; kehidupan seni budaya arsitektur, bidang keilmuan dan ilmu-ilmu keagamaan. Ketiga, pada Kerajaan Moghal kegiatan pendidikan yang nampak berkembang adalah kegiatan pendidikan disegala bidang seni. 
JURNAL PENDIDIKAN ISLAM IQRA' Vol. 11. Nomor 1

Fakultas Tarbiyah dan Ilmu Keguruan [FTIK]

IAIN Manado

\section{Daftar Pustaka}

A. Hasjmy, 1993. Sejarah Kebudayaan Islam, Jakarta: Bulan Bintang.

Ahmed Akbar S. 1992. Discovering Islam. Making Sence Of Muslim History and Society Terjemahan Nunding. dkk., Citra Muslim Tinjauan sejarah dan Sosiologi Jakarta: Erlangga.

Hodson Marshal G.S. 1981. The Venture of Islam, Volume III, Chichago: The University of Chichagi Pressm.

Ikatan Dosen Kewiraan Sulawesi, 1990. Pendidikan Kewiraan, Ujung pandang: Yayasan Pengembangan Ilmu dan Teknologi.

Lapidus, Ira. 1999. A History of Islamic Societies, Penerjemah, Ghuiran A. Mas'adi, Sejarah Sosial Umat Islam. Jakarta : PT. Raja Grafindo Persada.

Mahmud, Natsir. Tt. Orlentalisme Al-Qur'an di Masa Barat: Sebuah Studi Evaluative, Semarang: Dina Utama.

Nasution, Harun. 1992. Pembaruan dalam Islam; Sejarah pemikiran dan Gerakan, Jakarta Bulan Bintang.

Shihab, Quraish. 1998. Membumikan Al-Qur'an, Bandung: Mizan.

Yatim, Badri. 1993. Sejarah Peradaban Islam Dirasah Islamiyah II, Jakarta: Raja Gravindo Persada. 